\title{
Design, workspace analysis and inverse kinematics problem of Delta parallel robot
}

\section{Szep*, S.-D. Stan**, V. Csibi***}

Technical University of Cluj-Napoca, C. Daicoviciu no. 15, 400020, Cluj-Napoca, Romania, E-mail:szep_crysty84@yahoo.com

Technical University of Cluj-Napoca, C. Daicoviciu no. 15, 400020, Cluj-Napoca, Romania, E-mail: sergiustan@ieee.org Technical University of Cluj-Napoca, C. Daicoviciu no. 15, 400020, Cluj-Napoca, Romania, E-mail: csibiven@yahoo.com

crossref http://dx.doi.org/10.5755/j01.mech.17.3.506

\section{Introduction}

Parallel robots have a number of advantages over the traditional serial robots due to their particular architecture [1-10]. In this paper a structure of Delta parallel robot will be presented. An analysis about the kinematics problems of this structure will be made. Also, it will be presented the work space of Delta robot and it will be realized a GUI (Graphical User Interface) simulation of this structure in Matlab.

\section{The description, parameterization and CAD model for Delta parallel robot}

Geometric parameters for DELTA parallel robot arte presented in Table 1 and Fig. 1. This type of robot has in its structure three rotation motors positioned at 120 degrees one towards other.

The CAD model for Delta parallel robot was real-

Table 1

Construction parameters for delta parallel robot

\begin{tabular}{|l|c|}
\hline Construction parameters: & $L_{i}, R_{i}, l_{i}, r_{i}, q_{i}, i=1 \ldots 3, \mathrm{~mm}$ \\
\hline Parameterization: & $A_{i} B_{i}=R_{1} ; B_{i} C_{i}=L_{1} ; C_{i} D_{i}=l_{1} ; D_{i} E_{i}=r_{1}$ \\
\hline
\end{tabular}

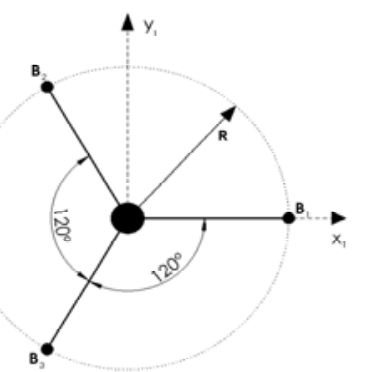

a

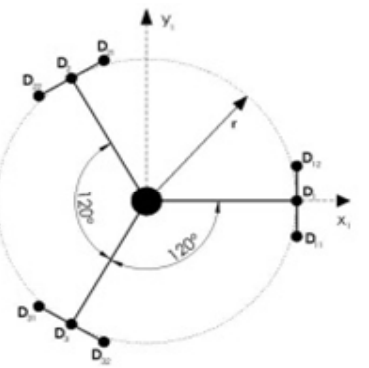

b

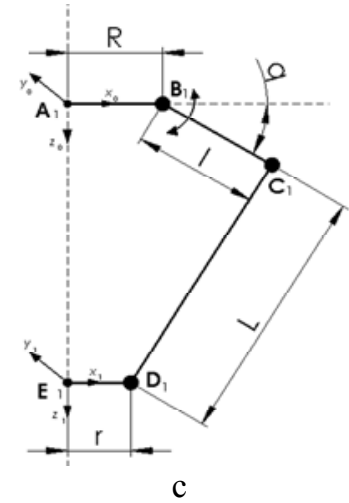

Fig. 1 Geometric parameters for Delta parallel robot structure: $a, b$ and $c$ ized in Solid Works and it's presented in Fig. 2, a and b. In Fig. 2, a is presented a structure of Delta parallel robot how has rotation joints in his configuration and in Fig. 2, b is the structure that contains spherical joints. Both structures are used in industry for different operations, but the one with spherical joints is more common.

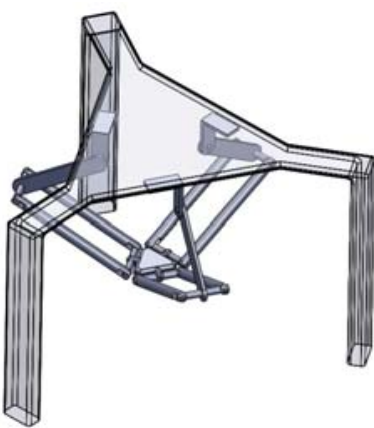

a

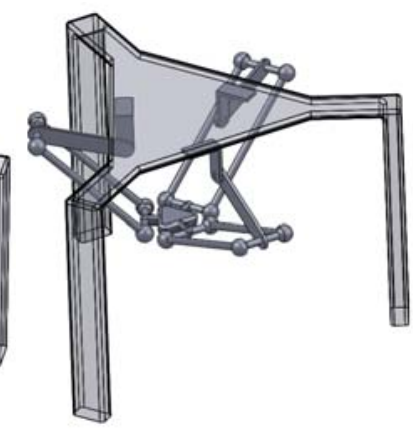

$\mathrm{b}$
Fig. 2 Delta parallel robot: a) with rotation joints; b) with spherical joints

\section{Inverse kinematics problem (IKP) for Delta parallel robot}

Inverse kinematics problem results from the determination of angle values $q_{i}(i=1,2,3)$ when the position of the characteristic point or the final effector (TCP Tool Centre Point), respective the general coordinates: $x_{p}, y_{p}, z_{p}$.

For the solution of $q_{1}$ angle the next equations will be used

$$
\begin{aligned}
a_{1}= & x^{2}+y^{2}+z^{2}+\frac{2 y l}{\sqrt{3}}-\frac{2 y L}{\sqrt{3}}+\frac{l^{2}}{3}-\frac{2 l L}{3}+\frac{L^{2}}{3}+l_{1}^{2}-l_{2}^{2}(1) \\
b_{1} & =2 y l_{1}+\frac{2 l l_{1}}{\sqrt{3}}-\frac{2 L l_{1}}{\sqrt{3}} \\
c_{1} & =2 z l_{1}
\end{aligned}
$$

Variables $a_{1}, b_{1}$ and $c_{1}$ will be used in final equation that will solve $q_{1}$ angle, the angle from the first link motor. For $q_{1}$ angle appears to be two solutions

$$
q_{1}=-\operatorname{atan}\left(c_{1}, b_{1}\right)+\operatorname{acos}\left(\frac{a_{1}}{\sqrt{b_{1}^{2}+c_{1}^{2}}}\right)
$$




$$
q_{1}=\operatorname{atan}\left(c_{1}, b_{1}\right)-\operatorname{acos}\left(\frac{a_{1}}{\sqrt{b_{1}^{2}+c_{1}^{2}}}\right)
$$

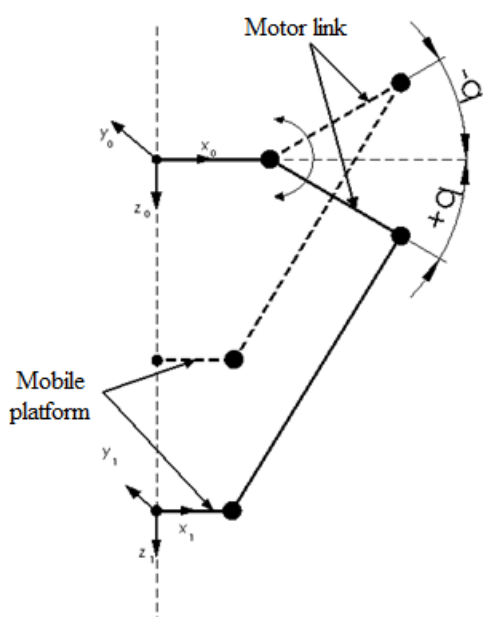

Fig. 3 Representation of the two solutions for the first motor link of Delta parallel robot (4) and (5)

As it can be observed two solutions are admitted for two possible position solutions for the first motor link (Fig. 3). From these two solutions it will be chosen the first solution because with this one the result of the equation is the correct value for our angle. The same procedure will be applied to compute next two angles of the other two motor links.

In conclusion, equations $\left(q_{1}, q_{2}, q_{3}\right)$ represent the analytic solutions for inverse kinematic models of Delta parallel robot.

Table 2 presents the computing algorithm for inverse kinematic problem of Delta parallel robot with rotation actuators.

Table 2

Algorithm variables for solving inverse kinematic problem of delta parallel robot with rotation actuators

\begin{tabular}{|l|c|l|}
\hline \multicolumn{3}{|c|}{ Inverse kinematic problem } \\
\hline & Variable symbol & Computing relations \\
\hline Input variables & $x, y, z$ & $(1),(2),(3)$ \\
\hline Computed variables & $q_{1}, q_{2}, q_{3}$ & $(4),(5)$ \\
\hline Output variables & $q_{1}, q_{2}, q_{3}$ & $(4),(5)$ \\
\hline
\end{tabular}

Table 3

Numerical solutions for inverse kinematic problem of delta parallel robot with rotation actuators

\begin{tabular}{|c|c|c|c|c|c|}
\hline \multicolumn{3}{l}{$\begin{array}{l}\text { Input values: } \\
\text { Operational coordinates }\end{array}$} & \multicolumn{3}{l|}{ Output values: } \\
\hline$X, \mathrm{~mm}$ & $Y, \mathrm{~mm}$ & $Z, \mathrm{~mm}$ & $q_{1},{ }^{\text {o }}$ & $q_{2},{ }^{\text {o }}$ & $q_{3},{ }^{\circ}$ \\
\hline 10 & 0 & 260 & -16.5289 & -14.1363 & -18.8629 \\
\hline 10 & 5 & 265 & -15.7029 & -15.3877 & -19.9880 \\
\hline 20 & 10 & 270 & -15.0148 & -14.3884 & -23.3407 \\
\hline 20 & 25 & 285 & -12.9532 & -18.1325 & -26.4292 \\
\hline 25 & 15 & 295 & -16.6325 & -16.6325 & -26.9964 \\
\hline 35 & 30 & 305 & -14.4626 & -18.0213 & -31.4846 \\
\hline 30 & 20 & 310 & -17.2459 & -18.1951 & -29.7111 \\
\hline 45 & 70 & 320 & -7.9557 & -23.4365 & -39.0348 \\
\hline 65 & 45 & 325 & -14.4766 & -17.0799 & -39.9995 \\
\hline 90 & 90 & 390 & -15.7478 & -26.9833 & -52.2323 \\
\hline
\end{tabular}

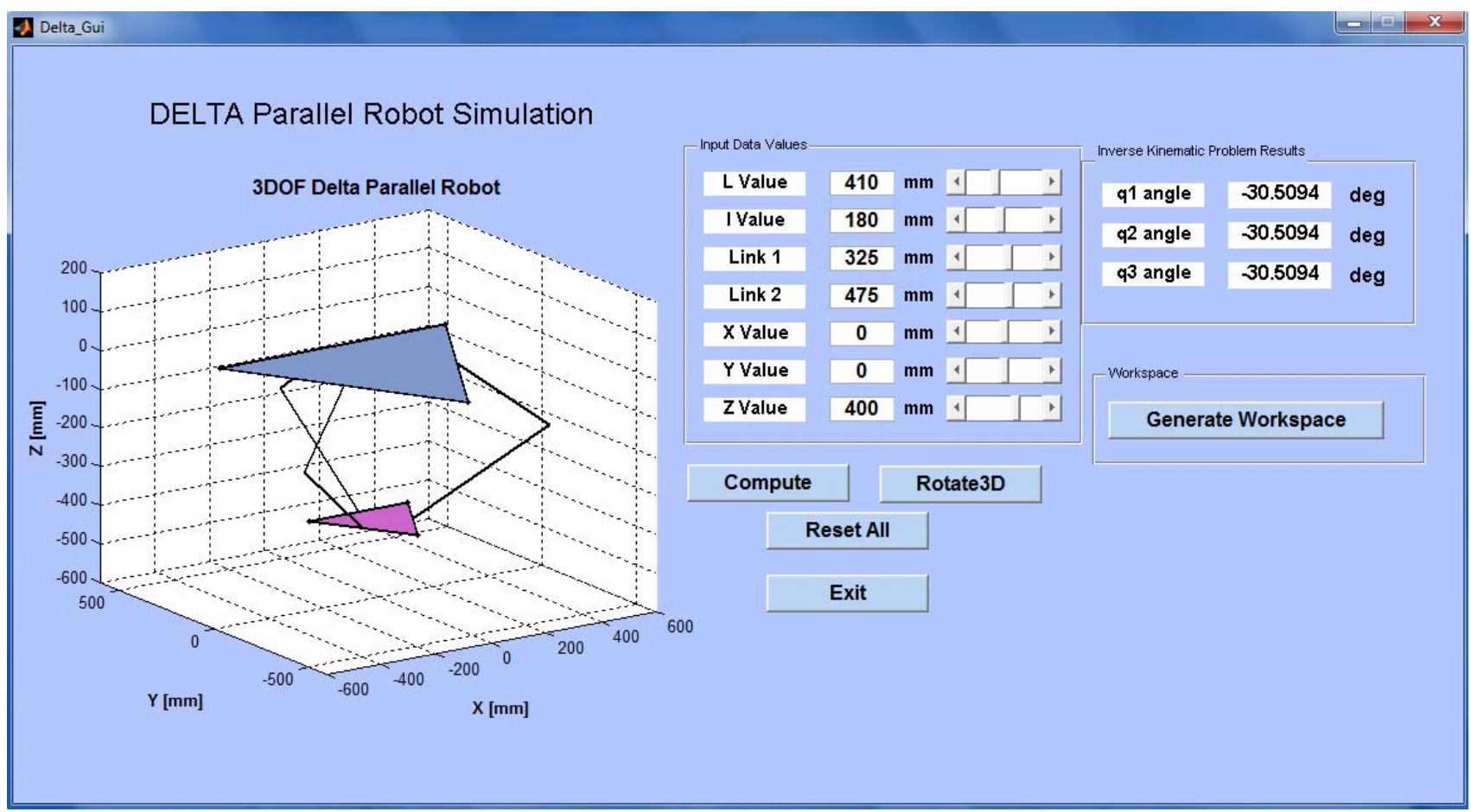

Fig. 4 Graphical user interface for solving the inverse kinematic problem of Delta parallel robot

In Fig. 4 graphical user interface realized in Matlab for solving the inverse kinematic problem of Delta parallel robot is presented.

In Table 3 is presented a set of numerical and experimental results obtained with help of the graphical user interface presented in Fig. 4. The developed GUI im- plements the Forward and Inverse kinematics of a 3DOF DELTA parallel manipulator. It provides the options to modify the geometry of the manipulator.

GUI is provided to visualize forward/inverse kinematics, end effector workspace, and position control of a 3DOF Delta parallel manipulator. The files are created as 


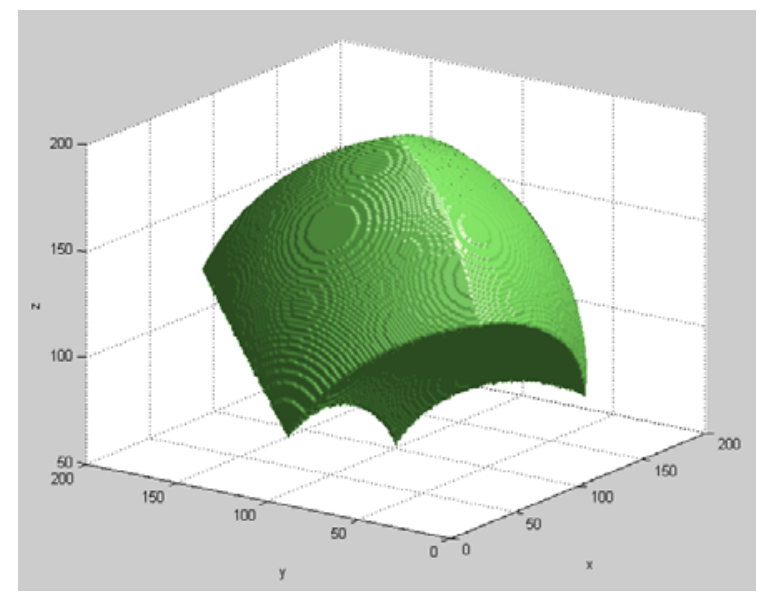

a

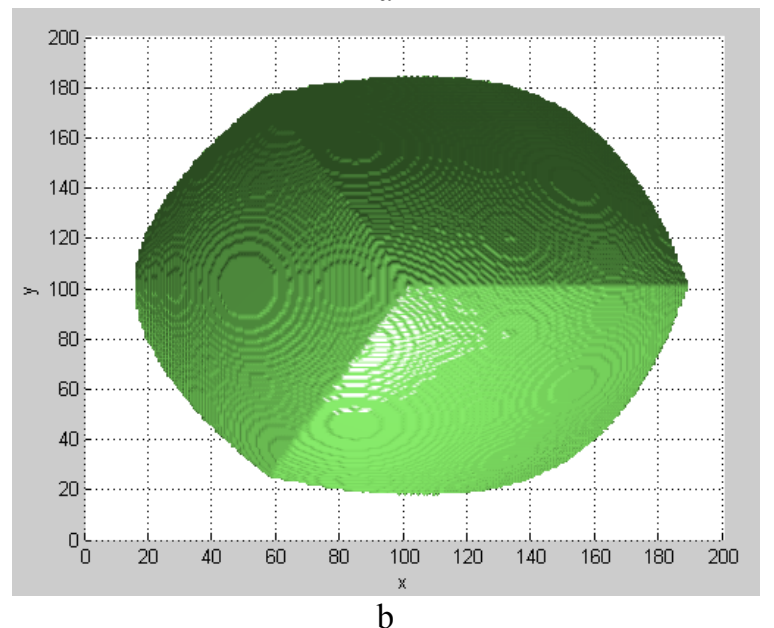

b
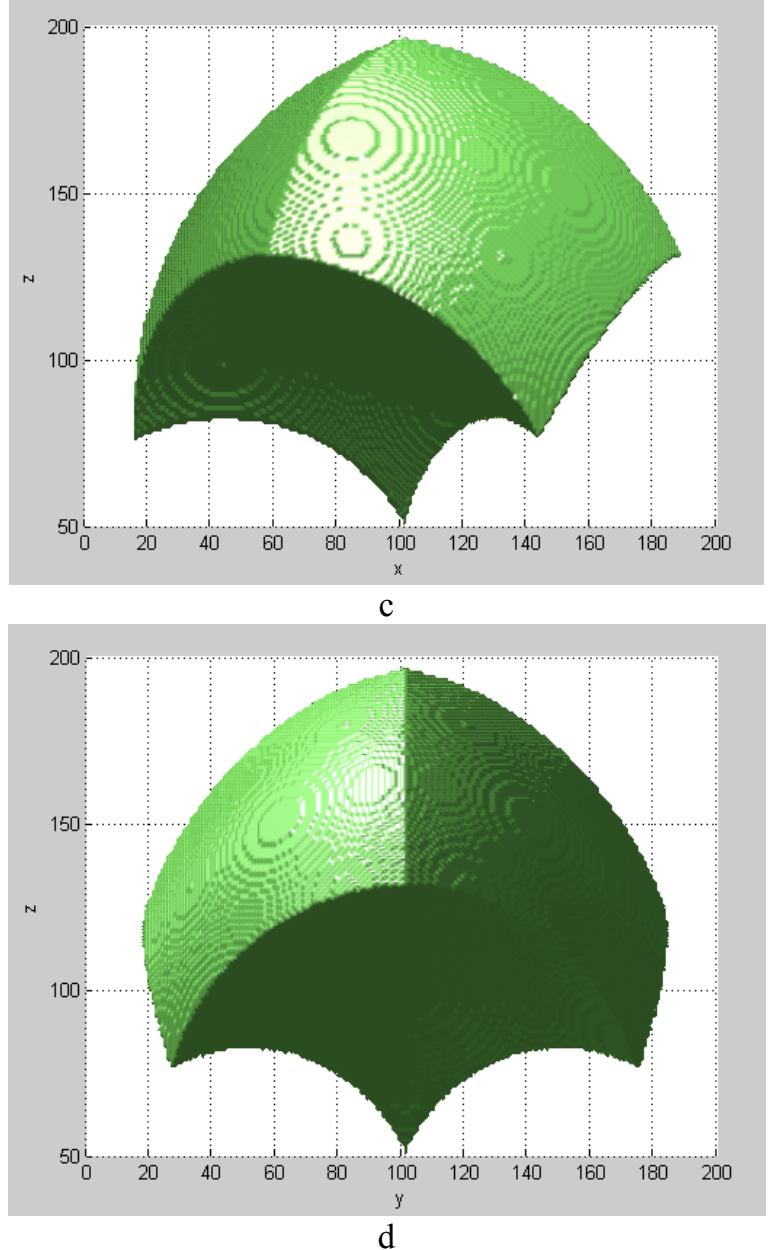

Fig. 5 Workspace of the 3DOF Delta parallel robot a part of the research project for the Department of Mechatronics at Technical University of Cluj-Napoca.

\section{Workspace analysis for Delta parallel robot}

One of the most important issues in the process of design of the parallel robots is to determine their workspace. For parallel robots, this issue may be even more critical since parallel robots will sometimes have a rather limited workspace. Various numerical methods for workspace determination of the parallel robots have been developed in recent years.

The following figures visualize the $3 \mathrm{D}$ robot workspace (Fig. 5, a - d).

The majority of numerical methods used for parallel manipulator workspace boundary determination typically rely on manipulator's pose parameter discretization. With the discretization approach, the workspace is envisioned as the uniform grid of nodes in a Cartesian or polar coordinate system.

Each node is then examined in order to determine whether it belongs to the workspace or not. The accuracy of the workspace boundary in this case depends on the sampling step, used to create the grid.

\section{Conclusions}

A description of the workspace of the parallel robot is provided based on the analysis of the robot. The kinematics and workspace analyses presented in this paper can greatly benefit the design, trajectory planning and control of such a parallel robot. For the simulation, we used an evaluation model from the Matlab/SimMechanics. Especially nonexperts will benefit from the proposed visualization tools, as they facilitate the modeling and the interpretation of results.

\section{Acknowledgment}

This work was financially supported by CNMP through the grants No. 3280 (PARTENERIATE type), title of the project 'Complex mechatronics systems for medical applications'.

\section{References}

1. Stan, S.-D.; Manic, M.; Mătieş, M.; Bălan, R. 2008. Evolutionary approach to optimal design of 3 DOF Translation exoskeleton and medical parallel robots, HSI 2008, IEEE Conference on Human System Interaction, Krakow, Poland, May 25-27, 2008: 720-725.

2. Stan, S.-D; Manic, M.; Mătieş, M.; Bălan, R. 2008. Kinematics analysis, design, and control of an Isoglide3 parallel robot (IG3PR)", IECON 2008, The 34th Annual Conference of the IEEE Industrial Electronics Society, Orlando, USA, November 10-13, 2008: 26362641.

3. Stan, S.; Mătieş, V.; Bălan, R. 2006. Optimal design of 2 DOF parallel kinematics machines, Berlin, Willey PAMM Proc. Appl. Math. Mech. 6, 705-706.

4. Brisan, C.; Rusu, C. 2008. Aspects concerning modeling of self-reconfigurable parallel robots, Mechanika 1(69): 59-62.

5. Tatar, O.; Mandru, D.; Ardelean I. 2007. Develop- 
ment of mobile minirobots for in pipe inspection tasks, Mechanika 6(68): 60-64.

6. Stan, S.-D.; Bălan, R.; Mătieş, V. 2008. Modelling, design and control of $3 \mathrm{DOF}$ medical parallel robot, Mechanika 6(74): 68-71.

7. Neagoe, M.; Gogu, G.; Diaconescu, D. High degree accuracy modelling and calibration of serial robots with large errors, D. Talaba and T. Roche (eds.), Product Engineering, Springer-Verlag: 397-408.

8. Gogu, G. 2004. Structural synthesis of fully-isotropic translational parallel robots via theory of linear transformations, European Journal of Mechanics / A Solids, vol. 23: 1021-1039.

9. Verdes, D.; Stan, S.-D.; Balan, R.; Coman, M. 2010. Study of design, kinematics and virtual control of 4 degrees of freedom parallel robot, Mechanika 2(82): 7074.

10. Rat, N.R.; Neagoe, M.; Diaconescu, D.; Stan, S.D. 2011. Dynamic simulations regarding the influence of the load-rigidity correlation on the working accuracy of a medical Triglide parallel robot, Mechanika 17(2): $178-181$.

C. Szep, S. D. Stan, V. Csibi, V. Balan

\section{LYGIAGREČIOJO DELTA ROBOTO} PROJEKTAVIMO, DARBO ERDVĖS IR ATVIRKŠTINĖS KINEMATIKOS PROBLEMOS

Re z i u m è

Nagrinèta nuolat kintanti darbo erdvè, kuri yra visų galimų mobilios platformos orientacijų nustatytoje pozicijoje visuma. Roboto projektavimas susideda iš jo geometrinių parametrų skaičiavimo, užtikrinančio judančios platformos padèti nustatytos darbo erdvès viduje.
C. Szep, S. D. Stan, V. Csibi, V. Balan

DESIGN, WORKSPACE ANALYSIS AND INVERSE KINEMATICS PROBLEM OF DELTA PARALLEL ROBOT

S u m m a r y

The constant-translation workspace, which is the set of all feasible orientations of the mobile platform for a given position, was studied. The design of the robot concerns geometric parameters calculation of the robot so that the moving platform would be found within the given workspace.

Ц. Сзеп, С.-Д. Стан, В. Цсиби, В. Балан

ПРОБЛЕМЫ ПРОЕКТИРОВАНИЯ, РАБОЧЕГО

ПРОСТРАНСТВА И ОБРАТНОЙ КИНЕМАТИКИ ПАРАЛЛЕЛЬНОГО ДЕЛЬТА РОБОТА

P е 3 ю м е

Рассмотрена постоянно меняющееся рабочее пространство, которое является совокупностью всех возможных ориентаций мобильной платформы в заданной позиции. Проектирование робота состоит из расчета его геометрических параметров, определяющих положение мобильной платформы внутри заданного рабочего пространства.

Received December 27, 2010 Accepted June 10, 2011 